\title{
Brás Cubas: um estudo na construção do defunto autor na literatura e no cinema
}

\author{
Bruna Canellas de Freitas ${ }^{\mathrm{i}}$
}

\begin{abstract}
RESUMO
Neste artigo, nos dedicamos a desenvolver um diálogo comparativo entre o romance Memórias Póstumas de Brás Cubas (1881), do autor oitocentista Machado de Assis, e sua adaptação cinematográfica Memórias Póstumas (2001), do diretor e roteirista André Klotzel (com diálogos de José Torero). Considerando a potência significativa do texto literário, mediante as escolhas efetuadas na releitura fílmica, temos à vista que o cineasta precisou enfrentar o desafio de transpor a complexa construção do defunto autor como o narrador machadiano em Memórias Póstumas de Brás Cubas - por ser aclamado como o projeto literário machadiano que revolucionou o modelo de romance no Brasil.
\end{abstract}

Palavras-chave: Machado de Assis; André Klotzel; Transposição midiática; Defunto autor; Literatura e Cinema.

\begin{abstract}
In this article, we dedicate ourselves to develop a comparative dialogue between the novel The Posthumous Memoirs of Brás Cubas (1881), by the 18th century author Machado de Assis, and his film adaptation Posthumous Memoirs (2001), by director and screenwriter André Klotzel (with dialogues by José Torero). Considering the significant power of the literary text, through the choices made in the film reinterpretation, we have the view that the filmmaker had to face the challenge of transpose the complex construction of the deceased author as the Machadian's narrator The Posthumous Memoirs of Brás Cubas for being acclaimed as the Machadian's literary project that revolutionized the model of romance in Brazil.
\end{abstract}

Keywords: Machado de Assis; André Klotzel; Media Transposition; Deceased Author; Literature and Cinema.

\section{CONSIDERAÇÕES INICIAIS}

\footnotetext{
${ }^{i}$ Mestra em Estudos Literários pelo Programa de Pós-Graduação em Letras e Linguística (PPLINFFP/UERJ).

E-mail: bruna.canellas92@gmail.com
} 
As adaptações dos textos literários para as telas do cinema têm seus caminhos cada vez mais entrelaçados. E essa relação sob o olhar do senso comum nem sempre aconteceu de forma harmoniosa. Ao compararmos duas mídias, ainda enfatizamos questões referentes à fidelidade da adaptação cinematográfica, uma vez que o texto literário em relação à adaptação é visto como superior e esta, como decorrência, valorizada em função da sua semelhança àquele. Nossa proposta (RIBAS, 2017) implica em compreender como a adaptação de um texto literário precisa ser pensada em sua própria força significativa, seu contexto de produção específico, agregando sentido ao texto de partida. Ao mesmo tempo, é uma perspectiva que entende, como rico material de análise, o procedimento de passagem de uma mídia à outra, com suas especificidades. Obviamente o trabalho é intensivo e, desenvolvê-lo implica escolher, recortar tópicos para empreender uma análise sob o viés das Intermidialidades, que é um derivativo da Literatura Comparada.

Vale explicitar, aqui, os sentidos que estamos atribuindo ao termo mídia, pertinente ao Estudo das Intermidialidades. Adalberto Müller (2009) explica que o termo "mídia" pode ser usado corretamente em dois sentidos: quando utilizado sempre no singular irá nos remeter no sentido de meios de comunicação de massa, tais como televisão, jornais ou rádios; quando utilizada no singular e/ou plural, é no sentindo de suporte físico para gravação ou transmissão (som, imagem, entre outros). Por esta perspectiva, Cinema e Literatura são considerados mídias que vão se interrelacionar dos mais diversos modos.

O recorte em estudo neste artigo está relacionado ao romance machadiano Memórias Póstumas de Brás Cubas e sua adaptação realizada por André Klotzel, aliando livro e filme. Assim, a análise desenvolvida está orientada a partir do conceito da transposição midiática, tratando preferencialmente do processo de migração entre as mídias ao invés da adaptação como resultado final. Desta forma, nossa atenção estará voltada mais às estratégias da tradução de uma mídia para a outra, ressaltando suas particularidades, possibilidades e limites. Traremos brevemente sobre a recorrente tendência em identificar e evidenciar a fidelidade ao texto literário como critério de valorização da adaptação (além da recorrência em hierarquizar as obras em diálogo), como consequência de nossa proposta de estudo. 


\section{DA LITERATURA PARA O CINEMA: UM ESTUDO DA TRANSPOSIÇÃO MIDIAL}

Quando falamos em Literatura e Cinema, logo pensamos nas adaptações. E um questionamento que se é levantado é em relação à fidelidade. E ao pensarmos em Literatura e Cinema, como duas mídias distintas, temos que analisar, primeiramente, questões que são de grande importância, no que diz à relação do texto de partida (texto literário) com a adaptação cinematográfica, uma vez que temos questões referentes à fidelidade e valoração com a obra a qual foi adaptada mídia cinematográfica.

Sendo assim, devemos pensar que a adaptação irá manter uma relação de intertextualidade como a obra de partida. Com isso, as adaptações buscam apresentar uma autonomia significativa, conservando características do texto de partida e trazendo uma nova roupagem da narrativa.

As adaptações dos textos literários para as telas do cinema nos permitem olhar a obra adaptada como um processo de (re)criação - ou mesmo (re)interpretação - do texto literário, em que o roteirista, ao propor uma adaptação, já lançou previamente um novo olhar de vislumbre à obra a qual se deseja adaptar.

\footnotetext{
O texto adaptado, portanto, não é algo a ser reproduzido, mas sim um objeto a ser interpretado e recriado, frequentemente numa nova mídia. É o que um teórico chama de reservatório de instruções - diegéticas, narrativas e axiológicas - que podem ser utilizadas ou ignoradas, pois o adaptador é um intérprete antes de se tornar criador. (GARDIES, 1998, p 68 - 71 apud HUTCHEON, 2013, p. 123)
}

Literatura e Cinema devem ter sua autonomia significativa, conforme nos afirma BRITO (2006), pois estão distanciados na escala do tempo e cada um destes suportes deve servir de mútuo apoio em sua suplementariedade narrativa - o que podemos afirmar dialogando com RIBAS $(2016,2017)$ - tendo em perspectiva o fato de que são suportes com demarcadas distinções e especificidades.

É importante destacar que o deslocamento do texto literário para uma nova mídia requer uma análise pontual sob o enfoque das Intermidialidades - termo cuja compreensão alude à sua duplicidade, traduzindo-se como categoria teórica e dimensão crítica, no campo das Letras (DINIZ, 2012), uma vez que o estudo das Intermidialidades 
consiste no esforço em laborar esta abordagem para além do campo da Comunicação seu nicho acadêmico habitual.

Irina Rajewsky (RAJEWSKY, 2012b, p. 58) evidencia este processo como sendo transposição midiática - conforme o plano de análise que adotamos - pois se correlaciona conceitualmente como uma subcategoria da Intermidialidade, cujo objetivo reside no desvendar das possibilidades materiais e das convenções vigentes para que seja possível desenvolver, em dimensão específica e pontual, a adaptação do texto literário para o cinema.

\begin{abstract}
Intermidialidade no sentido mais restrito de transposição midiática [...] aqui, a qualidade intermidiática tem a ver com o modo de criação de um produto, isto é, com a transformação de um determinado produto da mídia (um texto, um filme, etc) ou de substrato em outra mídia [...] cuja formação é baseada num processo de transformação específico da mídia e obrigatoriamente intermidiático (RAJEWSKY, 2012, p. 24).
\end{abstract}

Considerando como concepção genética da Intermidialidade, Rajewsky elenca a transposição midiática estando conectada ao processo de produção das adaptações fílmicas dos textos literários, lembrando que este critério relaciona-se, por sua vez, à configuração midiática já estabelecida e, portanto: “o texto ou o filme 'originais' são a 'fonte' do novo produto de mídia, cuja formação é baseada num processo de transformação específico da mídia e obrigatoriamente intermidiático.” (RAJEWSKY, 2012a, p. 24). E, neste sentido, ressaltemos que

\footnotetext{
O romance e o filme são basicamente iguais em termos de capacidade de significar. Eles significam, sim, diferentemente. Os dois meios, porém, usam e distorcem o tempo e o espaço, e ambos tendem a usar linguagem figurativa ou metafórica. (JOHNSON, 1982, p. 29)
}

Seguindo nesta linha de análise, é recomendável pensar a forma com a qual a adaptação fílmica de um romance se empenhará em manter uma relação de intertextualidade com o seu texto de partida. De acordo com Linda Hutcheon, "a adaptação é uma derivação que não é derivativa, uma segunda obra que não é secundária" (HUTCHEON, 2013, p.30), tão logo, uma obra existir dentro de outra obra, mas não estabelecendo uma lógica de complemento e sim uma lógica de suplemento (RIBAS, 2016). 
Ao desvendar as possibilidades materiais e as convenções vigentes para o desenvolvimento satisfatório da Intermidialidade entre as narrativas literária e fílmica, a transposição midial ressignifica a obra de partida por meio da lógica derridiana de suplemento (NUNEZ \& RIBAS, 2017), em que a conjugação transposição midiática/adaptação caracteriza e ilumina o modo com o qual os romances literários têm almejado e conquistado autonomia significativa no processo de sua releitura em tela e cenas. O conceito de Adaptação, portanto, integra-se ao conceito de transposição midiática como subcategoria das Intermidialidades, salva a diferença de que a adaptação relaciona-se com mais interesse ao resultado ("texto de chegada"), bem os estudos intermidiais ao processo de transposição.

Vale mencionar, também, que, em sendo um derivativo da Literatura Comparada, com visão não hierarquizante, e deslizando da centralidade do texto literário como cânone, a abordagem intermidial conversa com a Desconstrução francesa, que teve seu auge na década de 60 do século XX. Vejamos a seguir como se processa este diálogo.

A partir da concepção derridiana, Silviano Santiago, considera que suplemento "é uma adição, um significante disponível que se acrescenta para substituir e suprir uma falta do lado do significado e fornecer o excesso de que é preciso.” (SANTIAGO, 1976, p. 88); isto é, não se trata de um complemento obrigatório para compor o sentido, mas algo que pode - e não - estar ali. E de acordo com Derrida, temos que o conceito de suplemento "é aquilo que se parece acrescentar como um pleno a pleno, também é aquilo que supre" (DERRIDA, 1995, p. 200). Desta maneira, a noção de suplemento será um adicional não essencial que tem como fidelidade acrescentar/adicionar algo que por si só já está completo, assim como é o texto literário e com isso traz um novo olhar para o texto de partida. A noção de suplemento foi trazida por Maria Cristina Ribas (2016) para o entendimento da adaptação de textos literários pelo cinema.

O suplemento, portanto, não está precisamente nem dentro nem fora, não se configura como ausência ou presença; configura-se fundamental àquilo que suplementa, mas aponta para um acréscimo que pode ser retirado. A noção desfaz o nexo solidário e hierarquizante entre o literário e adaptação fílmica e, em decorrência, desconstrói a ideia de necessária complementaridade em prol de um sentido totalmente acabado. (NUNEZ \& RIBAS, 2016, p. 499)

De acordo com Robert Stam (2006) adaptações de obras literárias são vistas como perdas em relação ao seu texto-fonte, visto que se tem observado o poder de superioridade 
que a literatura tem sobre a chamada adaptação. Stam nos fala ainda que os estudos voltados para a teoria da intertextualidade reformularam os estudos da adaptação; e, do modo como Silviano Santiago traz para o campo da literatura, Stam traz aos estudos da Adaptação a Desconstrução de Derrida, que desfazia, conforme citamos, a concepção hierarquizante entre obra em original e cópia, sem adoção de um centro de origem e supervalorização do texto-fonte. Sendo assim: numa perspectiva derridiana, o prestígio aural do original não vai contra a cópia, mas é curiosamente criado pelas cópias, sem as quais a própria ideia de originalidade perde o sentido.

O filme enquanto "cópia", ademais, pode ser o "original" para as "cópias" subsequentes. Uma adaptação cinematográfica como "cópia", por analogia, não é necessariamente inferior à novela como "original". A crítica derridiana das origens é literalmente verdadeira em relação à adaptação. (STAM, 2006, p. 22)

Klotzel ainda levanta a questão sobre a fidelidade em relação à adaptação do texto literário para as telas do cinema:

\begin{abstract}
Alguém pode pensar que a fidelidade ao texto deveria resultar em uma adaptação que seria a edição dos trechos mais significativos mantidos o mais próximo, se possível iguais ao original literário - uma espécie de resumo visual do livro. Essa pessoa estaria desprezando o sentido particular de cada forma de expressão e ignoraria que um texto literário ilustrado por imagens resulta geralmente em algo completamente diferente do livro lido. A literatura, por mais que seja descritiva, não mostra o objeto visual com imagens físicas como no cinema e, por outro lado, ela pode usar elementos abstratos que são impossíveis de serem filmados, como o pensamento e os sentimentos de personagens. O leitor define como, quando e com quê interrupções fará a leitura. Em um filme essa possibilidade não é relevante; são linguagens diferentes. Portanto, vamos estabelecer desde já que numa adaptação cinematográfica ser fiel a um livro não passa obrigatoriamente por tentar manter no filme o máximo de coisas iguais ao original literário. (KLOTZEL, Uma questão de fidelidade).
\end{abstract}

Tais questões são melhores compreendidas ao traçarmos como diretrizes de análise as seguintes vias: a(s) percepção (ões) do leitor/espectador como promotora(s) da contínua intertextualidade com o texto de partida; e, a intertextualidade entre as narrativas de cada suporte (livro e filme) que possibilita ao leitor/espectador uma rica diversidade quanto à apreciação de uma "mesma" obra registrada em distintas perspectivas. 


\section{O NARRADOR BRÁS CUBAS DE KLOTZEL}

O romance Memórias de Póstumas de Brás Cubas foi lançado inicialmente em formato de folhetim pela Revista Brasileira (entre o período março a dezembro de 1880) foi publicado em formato de livro em 1881, sendo um romance inovador, destacando-se pelo enredo e sua inovação no modo de narrar.

O romance de Machado de Assis teve duas outras versões antes da versão de Klotzel. A primeira delas, do diretor Fernando Coni Campos, lançada em 1968, intitulada Viagem ao fim do mundo, tendo como base dos capítulos do romance: $O$ Delírio e $O$ Senão. Sua segunda versão, Brás Cubas, teve seu lançamento, em 1985, sendo dirigida pelo diretor Júlio Bressane, este procurou levar a estrutura do romance de Machado de Assis a fim de preservar suas características. Sua terceira versão, lançada no Festival de Gramado de 2001, foi dirigida pelo diretor André Klotzel com roteiro de José Torero.

O narrador em Memórias Póstumas de Brás Cubas se apresenta como um narrador autodiegético, em que este se apresenta em primeira pessoa narrando suas experiências pessoais. Em contrapartida, podemos inferir que através da focalização em narrar Brás Cubas-personagem, o Brás Cubas-narrador se manifesta como homodiegético.

Em concordância com a pesquisadora Rosângela Cavalcanti Nuto (2006), André Klotzel, decanta Brás Cubas em duas personagens: (1) Brás-fantasma e (2) Brás-vivente. Brás-fantasma guia o espectador, com o olhar direcionado para a tela, se dirigindo aos espectadores do filme: "Você, espectador que se remexe na poltrona, tenha calma. Logo vamos entrar na história propriamente dita." (KLOTZEL \& TORERO, 1998, p. 2-3). Petrônio Gontijo dá vida a Brás-vivente e é personagem da própria história que será narrada pelo defunto autor:

Em Memórias Póstumas, Klotzel soluciona o problema do narrador reflexivo em primeira pessoa dividindo-o em dois. Além do recurso da voice-over, constante mente presente, ele também separa o Brás-fantasma do Brás-vivente. O fantasma de Brás é quem olha diretamente para a tela e se dirige ao espectador, chegando a solicitar que ele não fique nervoso com sua narração lenta e que "ajeite-se um pouco melhor na poltrona", num diálogo bastante próximo com o narrador satírico de Machado. O Brás-vivente faz parte da história narrada pelo fantasma de Brás. E embora em algumas sequências os personagens sejam congelados em seus movimentos para centralizar a atenção nos comentários do narrador, o Brás narrado desconhece a câmera, mantendo a representação naturalista. (NUTO, 2006, p. 94) 
E ao adaptar o romance de Machado de Assis, Klotzel, nos apresenta Brás Cubas como um narrador que vai mostrando a direção que o espectador terá que seguir, assim como Machado de Assis nos fez ao apresentar seu narrador, que seria uma espécie de guia para o leitor.

No capítulo XIII - "Salto" no romance machadiano, Brás Cubas chega à fase adulta. Em Memórias Póstumas, Klotzel utiliza a mesma estratégia narrativa que Machado de Assis. Tanto a narrativa literária quanto a narrativa fílmica a história tem um salto e chega em 1822: "Quem diria que... Suspendamos a pena; não adiantemos os sucessos. Vamos de um salto a 1822, data da nossa independência política e do meu primeiro cativeiro pessoal." (ASSIS, 2016, p. 50).

Ao transpor para o cinema, um narrador tão complexo como Brás Cubas, André Klotzel optou por colocar o defunto autor interagindo com o espectador, assim como acontece na narrativa de Machado de Assis. Sabadin afirma que:

\footnotetext{
Klotzel, que além de roteirizar e dirigir também montou o filme, optou por fazer com que o personagem principal se dirigisse diretamente ao público, olhando para a lente da câmera. Apesar de arriscada, a opção se mostrou das mais felizes. Primeiro porque é exatamente assim que Cubas fala com o leitor do livro original: direta e francamente. Segundo porque Klotzel tinha em mãos o grande talento de Reginaldo Faria, que conseguiu conectar o 'diálogo' com a platéia de maneira bastante empática (SABADIN, 2001, p. 1)
}

O defunto autor de Klotzel tem consciência dos recursos que são utilizados nos cinemas, pois logo no início do longa-metragem ele situa o espectador que não se encontra no século XIX, mas sim no século XX - período em que estava acontecendo o Cinema Novo. E de acordo com Silva Junior (2015), André Klotzel ao trazer o defunto autor para meados do século XX, não só nos mostra que Brás Cubas está narrando suas memórias 100 anos após sua morte, como também reatualiza suas memórias.

\footnotetext{
O narrador de Klotzel também é interessante por se situar e ter a autoconsciência de estar no cinema e também sabe que está em pleno século XXI. Como toda produção cinematográfica, a produção Brás Cubas apresenta algumas divergências com o romance, logo nas cenas iniciais. Em determinada parte do filme ele diz ter morrido há mais de 100 anos, sugerindo que Klotzel não apenas cria uma produção que responda ao romance, mas que também reatualiza suas memórias póstumas. (SILVA JUNIOR; NETO, 2015, p. 5)
}

Na sequência 21, o cineasta utiliza os quadros de Pedro Américo para marcar o ano da Independência. A voz do narrador surge em voz over, enquanto, Brás ainda jovem, 
desce do cavalo e segue a pé. É nesse momento que a câmera se desloca e surge o defunto autor com um travelling - e este dialoga com o espectador dizendo que era um jovem lindo e audaz. O defunto autor usa sua mão para indicar que a câmera deve seguir Brás Cubas jovem, mostrando mais uma vez que conhece os mecanismos utilizados pelo cinema,

Na festa da independência, eu e o país éramos dois rapazes, ambos surgindo para mostrar sua própria face.

O fantasma está entre os populares. Brás desmonta do cavalo e segue a pé, puxando o animal.

\section{FANTASMA}

Sim, este que vocês estão vendo aí, descendo do cavalo, sou eu. Podemos não parecer muito, mas só fisicamente. Essa imagem é o retrato mais fiel da minha robustez de espírito. Esse sorriso bonito é a maneira mais cinematográfica de mostrar meu entusiasmo. (KLOTZEL \& TORERO, 1998, p. 17)

Klotzel ao utilizar este recurso do freeze frame, mostra a interferência de um narrador autoconsciente das técnicas do cinema, que nos mostra um controle sobre a narrativa. Alves afirma que:

\footnotetext{
A interferência do narrador autoconsciente comanda a narrativa, desvendando aspectos da escrita autoconsciente comanda a narrativa, desvendando aspectos da escrita do próprio filme. Os congelamentos, as retomadas em flashback, as explicações dadas diretamente ao espectador enquanto as cenas permanecem congeladas, demonstram como o Brás fílmico é um narrador que tem consciência que está atuando como alguém que dirige seu próprio filme. (ALVES, 2013, p. 111)
}

Um aspecto interessante na adaptação de Klotzel é um recurso ao qual Louvel (2012) denomina por efeito quadro. Este recurso consiste em uma forte sugestão referenciada, ainda que indiretamente, entre a imagem/pintura e o texto, sendo assim o produto oriundo da narrativa de imagens e pinturas - seja no âmbito geral da pintura, seja no particular de um quadro específico. Neste sentido, ressaltamos a autoconsciência e explícito domínio/controle de Brás Cubas-narrador sobre os recursos utilizados nas narrativas literária e fílmica, aponto da primeira lançar luzes e sombras sobre a segunda.

Observamos também em algumas cenas que o fantasma de Brás Cubas interage com algumas personagens que estão presentes na cena. E esta interação fica evidente quando observamos na sequência 116 do roteiro, em que Brás Cubas entra na casa e 
Virgília está a sua espera e durante a discussão do casal Lobo Neves e Virgília, o fantasma de Brás entra comentando a briga, e se aproxima de sua amada Virgília e lhe dá um beijo na testa:

\begin{abstract}
No filme, há um segundo take, a cena é repetida, e quem dá o beijo desta vez é de fato o fantasma, o defunto autor e narrador on-screen. Klotzel se apropriou não apenas da fábula machadiana, mas também da estrutura narrativa do romance com o uso da autoconsciência e das digressões na figura do narrador on-screen, que se dirige ao espectador dando sua opinião ou o interpelando. (MENDES, 2013, p. 41)
\end{abstract}

O leitor machadiano é convidado pelo narrador a compartilhar a história do romance desde seu início. O narrador machadiano se aproxima do leitor a fim de forçar uma certa intimidade - ambígua - com o leitor, bem como na adaptação de André Klotzel em que o narrador, em todo momento dialoga com o espectador, mas lhe dá diversas agulhadas. Esta relação de provocação com o leitor, de sedução e traição, adulação e sarcasmo, é uma tradição que ganha força na literatura do século XIX.

O narrador está sempre presente, invadindo a cena e perturbando o ritmo do romance. Estas invasões que mexem com o leitor são as inovações no romance brasileiro que mais chamam a atenção da crítica nos romances machadianos. A narrativa machadiana é pontilhada de reflexões e de diálogos com o leitor, o que traz um clima especial ao ato de leitura: provoca nele a participação ativa no trabalho de construção do romance. (ROCHA, 2016, p. 20)

Rocha aponta que o narrador machadiano por diversas vezes para a narração a fim de dialogar com o leitor de diferentes modos "seja advertindo-o ou em tom de ameaça e ironia" (2016, p.19). No paratexto intitulado Ao leitor, o defunto autor Brás Cubas o leitor o modo de como seriam narradas suas memórias e que suas memórias continuariam a existir o leitor gostando ou não. O defunto autor diz que

\footnotetext{
Conseguintemente, evito contar o processo extraordinário que empreguei na composição destas Memórias, trabalhadas cá no outro mundo. Seria curioso, mas nimiamente extenso, e aliás desnecessário ao entendimento da obra. A obra em si é a mesma é tudo: se te agradar, fino leitor, pago-me da tarefa; se te não agradar, pago-te com um piparote, e adeus. (ASSIS, 2016, p. 23)
}

Melo e Souza considera que a originalidade do narrador machadiano reside na forma com que este narrador age e interage, desempenhando múltiplos e diferenciados 
papéis, demonstrando uma grande volubilidade forma com que se propõe a narrar. Sendo assim:

\begin{abstract}
A originalidade do narrador machadiano consiste em atuar como ator dramático, que assume e finge todo gênero de caracteres, desempenhando diferentes papéis, articulando uma alternância vertiginosa de perspectivas ou máscaras narrativas, modulando vários pontos de vista, sempre recusando a inflexão inercial de se imobilizar na representação doutrinária de um só papel, na adoção monológica de uma visão de mundo pretensamente normativa. (MELO E SOUZA, 2017, p. 1)
\end{abstract}

Um narrador que dissimula os fatos e as interpretações daquilo que pretende narrar/recordar em suas memórias póstumas nos é apresentado com magistral expressividade por Machado, haja vista

O narrador que finge múltiplas vozes ou que realiza a mímesis de várias atitudes nada tem de volúvel. Pelo contrário, cumpre a sublime função dramática de legítimo mediador dos sentidos culturalmente consentidos pelos diversos estratos sociais da comunidade histórica. Exemplo extremo e sério da representação da alteridade, o narrador singularizado como fingidor representa a disputa das ideologias em luta, e não o primado epistemológico de uma ideologia em particular. (MELO \& SOUZA, 2017, p. 1-2)

O narrador machadiano configura elemento fundamental da narrativa, pois se torna o próprio direcionamento através do qual o leitor será conduzido, modo com o qual a adaptação de Klotzel faz uso na narrativa fílmica. Sobre este aspecto verificamos que

\begin{abstract}
A presença do narrador torna-se o fio condutor de uma história em que é necessário confiar em sua visão, pois é testemunha dos acontecimentos, e o distanciamento que ocorre quando se tem que considerar o Brás Cubas que já não se encontra mais entre os vivos, mas defunto. Desse modo, ele se torna capaz de criticar, esboçar opiniões e fazer correções que, caso estivesse em vida não poderia fazê-lo. (ROCHA, 2016, p. 15)
\end{abstract}

Alfredo Bosi afirma que "a presença do narrador junto aos fatos dobra-se em autoconsciência" (2006, p. 9). Em outras palavras, verificamos que o narrador Brás Cubas, na qualidade de defunto autor é dotado de maior ampla liberdade para se expressar com mais autonomia, haja vista que este se torna concomitantemente autor e personagem de suas próprias memórias (póstumas).

Em concordância com Bosi, no que diz respeito à postura assumida pelo narrador e àquela esperada do leitor, podemos considerar que 


\begin{abstract}
A relação do narrador com o leitor move-se através de todas as variações de sadismo desde a aparente deferência até a aberta agressão. O olhar irônico aparece em expressões como "amado leitor", ou em passagens em que parece tratar o leitor como adulto, delegando-lhe o julgamento: "Vou expor-lhe sumariamente o caso. Julgue-o por si mesmo". E vai ao extremo de atribuir ao leitor comentários argutos que este não fez, e convidá-lo a colaborar no livro. (BOSI, 2006, p. 295)
\end{abstract}

Guimarães (1975) também nos traz à percepção que o salto retrospectivo perfaz um movimento partindo da morte do narrador/defunto autor Brás Cubas até seu nascimento, tecendo em imagem/simbologia a trajetória de um ciclo. Posteriormente ao salto na história de vida e morte de Brás Cubas, a narrativa estabelece uma cronologia nos acontecimentos narrados/recordados.

\title{
A CONSTRUÇÃO DO DEFUNTO AUTOR EM MEMÓRIAS POSTUMAS
}

Memórias Póstumas de Brás Cubas narra a história do defunto autor que, após sua morte - em agosto de 1869 -, decide narrar suas próprias memórias aproveitando a eternidade de que lhe fora dada, uma vez que possui uma liberdade para falar da sua vida bem como da sociedade que vivera ao seu próprio modo, já que se encontra morto e afastado quaisquer expressões de julgamento.

O defunto autor, ao iniciar suas memórias, alerta o leitor deixando claro que a principal virtude de um defunto é a franqueza. Brás Cubas, com seu jeito sarcástico, faz uma advertência aos leitores/espectadores: "a franqueza é a primeira virtude de um defunto" (ASSIS, 2016, p.69). Com isso:

\footnotetext{
Ao iniciar sua narrativa, o defunto-autor deixa claro a sua principal virtude: a franqueza, que somente os mortos têm o privilégio de possuir, por não deverem mais satisfação à sociedade. A partir de então, começa o relato dos fatos que marcaram sua vida desde o seu nascimento até a morte, sem deixar de lado a ironia, caracterítica marcante da personagem. (PEREIRA, 2008, p. 21-22)
}

Ao compreendermos a construção do defunto autor machadiano, nos deparamos com sua desenvoltura na condução da narravitiva. Em concordância com Patrick Pessoa (2007), Brás Cubas se coloca na posição de se recusar à saciar a curiosidade do 
leitor/espectador. $\mathrm{O}$ defunto autor se mantém no campo das aparências, se recusando a revelar ao leitor o processo de criação/recordação que compusera no "outro mundo".

\begin{abstract}
Entre a frivolidade e a gravidade, a simpatia que Brás Cubas espera angariar tem antes a ver com a curiosidade. É com o intuito de atiçar a curiosidade do leitor para o qual escreve, aquele que busca a verdade de sua ficção sem com isso renunciar ao prazer estético, que, no prólogo ao leitor, ele apresenta a sua teoria da interpretação de um "sujeito obscuro e truncado" (...), e portanto necessariamente provocativo. Cumpre ao leitor simpático ao seu autor explicitar e desenvolver essa teoria da interpretação; desincumbir-se da tarefa que ele próprio negligencia (PESSOA, 2007, p. 53)
\end{abstract}

É importante assinalar em nossa análise que, ao ler atentamente o romance, identificamos uma contradição/distinção interna entre o Brás Cubas defunto autor e o Brás Cubas narrador personagem, caracterizando sua disposição afetiva originada a partir deste paradoxo entre dois Brás Cubas distintos, mas complementares, haja vista que “(...) a posição do narrador nas Memórias só se constitui após a morte Brás Cubas. O Brás Cubas narrador só nasce quando morre "o Brás Cubas personagem. Eis a sua autêntica originalidade, a sua verdadeira origem: o fato de que para ele a "campa foi outro berço." (PESSOA, 2007, p. 60).

Segundo por esta linha de análise, vale mencionar que o questionamento sobre qual a razão existencial, a disposição afetiva, a paixão que se instalou na alma de Brás Cubas ainda em vida e o conduz na vida pós-morte a condição de um defunto autor que resolveu narrar/recordar suas Memórias. No que diz respeito à sua autocriação como defunto autor, podemos recomendar que Brás Cubas seja lido ao mesmo tempo como narrador personagem e personagem narrador. E, neste entendimento, é possível considerar que

O narrador (...) é convertido em uma espécie de leitor de si mesmo, dessa obra que é sua vida. E o leitor, impossibilitado de uma identificação plena com Brás Cubas pelo mesmo mecanismo que impede a identificação plena do narrador consigo mesmo, é forçado continuamente a assumir a responsabilidade pela (construção da) narrativa. Uma responsabilidade que, como já deve ter ficado claro, não deve ser total, pois de outro modo ficaria eliminada a alteridade da obra, única razão para lê-la; ou a alteridade da vida, única razão para vivê-la (ou, no caso, recordá-la). (PESSOA, 2007, p. 122)

O capítulo Óbito do autor (capítulo I) é um capítulo muito importante para o entendimento global do romance machadiano. Neste capítulo, Machado de Assis usa 
diversas palavras que vão se associar a vida e morte, uma vez que Memórias Póstumas começa a ser narrado pela morte do defunto autor e não pelo nascimento.

Memórias Póstumas de Brás Cubas é um romance cíclico. Machado de Assis une as pontas da vida que são nascimento e morte. Guimarães e Gomes dizem que: "A morte opõe-se à vida, referida, no início do texto, pelos termos princípio e nascimento, empregados para mostrar hesitação e discordância em relação ao uso vulgar, no dizer do locutor, de abrir memórias. A palavra vida volta no final do texto, na descrição do processo da morte, em a vida estrebuchava-me no peito." (2018, p. 77)

Tabela 1: Capítulo I - Óbito do autor

\begin{abstract}
Algum tempo hesitei se devia abrir estas memórias pelo princípio ou pelo fim, isto é, se poria em primeiro lugar o meu nascimento ou a minha morte. Suposto o uso vulgar seja começar pelo nascimento, duas considerações me levaram a adotar diferente método: a primeira é que eu não sou propriamente um autor defunto, mas um defunto autor, para quem a campa foi outro berço; a segunda é que o escrito ficaria assim mais galante e mais novo. Moisés, que também contou a sua morte, não a pôs no intróito, mas no cabo: diferença radical entre este livro e o Pentateuco.

Dito isto, expirei às duas horas da tarde de uma sexta-feira do mês de agosto de 1869, na minha bela chácara de Catumbi. Tinha uns sessenta e quatro anos, rijos e prósperos, era solteiro, possuía cerca de trezentos contos e fui acompanhado ao cemitério por onze amigos. Onze amigos! Verdade é que não houve cartas nem anúncios. Acresce que chovia - peneirava uma chuvinha miúda, triste e constante, tão constante e tão triste, que levou um daqueles fiéis da última hora a intercalar esta engenhosa idéia no discurso que proferiu à beira de minha cova: — "Vós, que o conhecestes, meus senhores, vós podeis dizer comigo que a natureza parece estar chorando a perda irreparável de um dos mais belos caracteres que têm honrado a humanidade. Este ar sombrio, estas gotas do céu, aquelas nuvens escuras que cobrem o azul como um crepe funéreo, tudo isso é a dor crua e má que lhe rói à Natureza as mais íntimas entranhas; tudo isso é um sublime louvor ao nosso ilustre finado.” (ASSIS, 2012, p. 23)
\end{abstract}

Fonte: Tabela elaborada a partir dos dados GUIMARÃES; GOMES, 2018

Brás Cubas logo no início do capítulo I se define como defunto autor e não como autor defunto. Ao trazermos os termos autor defunto e defunto autor, podemos compreender que quando Brás Cubas diz ao leitor que não é propriamente um autor defunto e sim um defunto autor, podemos entender que autor defunto é aquele que já faleceu e deixou sua obra como legado. E ao invertermos a expressão para defunto autor, podemos compreender que ao mudarmos o substantivo de posição e este passa a ser um 
adjetivo, quer dizer que Brás Cubas não era qualquer defunto e sim um defunto autor, aquele que irá narrar suas memórias sem se preocupar com a opinião dos outros.

Sobre esta relação dicotômica entre autor defunto e defunto autor, podemos também destacar que existe uma expressão marcadamente como uma metáfora alinhada à força da narrativa, pois Brás Cubas - já falecido - recorda/narra a história de sua própria vida, elencando os fatos que mais marcaram sua trajetória ao sabor e tons do seu próprio modo sarcástico e sedutor de narrar, exercendo sua posição de autoridade soberana na esfera da narrativa. Assim como em Memórias Póstumas de Brás Cubas, na adaptação de André Klotzel, identificamos um perene e controverso diálogo com o leitor/espectador por meio do qual as suas múltiplas intencionalidades de defunto autor são evidenciadas.

\begin{abstract}
Veja o leitor a comparação que melhor lhe quadrar, veja-a e não esteja daí a torcer-me o nariz só porque ainda não chegamos à parte narrativa destas memórias. Lá iremos. Creio que prefere a anedota à reflexão, como os outros leitores, seus confrades e acho que faz muito bem. Pois lá iremos. Todavia, importa dizer que este livro é escrito com pachorra, com a pachorra de um homem já desafrontado da brevidade do século (...). (ASSIS, 2012, p.).
\end{abstract}

Assim como na narrativa machadiana, a adaptação de Klotzel possui narrador que se comporta como um guia para o leitor/espectador. No caso da narrativa fílmica, percebemos que o uso da câmera confere relativa independência ao curso do processo de recordação das memórias, conferindo a cada cena da adaptação a oportunidade de nos mostrar a câmera como um narrador externo, alinhando esta potência discursiva às nuances ilustrativas presentes no romance machadiano. O narrador defunto autor Brás Cubas, ao interagir com o espectador, demonstra relativa consciência de todas as técnicas e recursos utilizados na mídia cinematográfica:

\footnotetext{
Em contrapartida, Klotzel demonstra grande inteligência ao modernizar (aí, sim!) o veículo narrativo de Memórias Póstumas de Brás Cubas. Aqui, Cubas não é um Fantasma-escritor, mas sim um Fantasma consciente dos maravilhosos recursos do Cinema. Com isso, ele assume a postura de estrela de seu próprio filme, brincando com a câmera e os espectadores. Além disso, o cineasta encontra uma forma criativa de contornar o orçamento limitado, que impede a reconstituição detalhada do Rio de Janeiro do século 19, e utiliza gravuras intercaladas à narrativa para ajudar o próprio espectador a recriar o visual da época em sua mente (VILLAÇA, 2001)
}

Nas sequências 41 e 42 podemos observar que Klotzel utilizou o efeito freeze frame. Na sequência, Brás está com seu pai Bento Cubas e, este fala que Brás precisa de 
dois motivos: "um lugar como deputado e um casamento" (KLOTZEL \& TORERO, 1998, 2001). Bento então diz o nome da noiva de Brás Cubas: Virgília. A cena então congela e mostra um deslocamento da câmera e Brás Cubas fantasma (nomenclatura adotada por André Klotzel) entra em cena dialogando com o espectador: "Ooops! Uma explicação. Virgília... Virgília é aquela do começo do filme. Não sei se o espectador vai se lembrar, então por via das dúvidas, vamos rememorar." (KLOTZEL \& TORERO, 1998, p. 34).

Em seguida Brás cruza o quadro e sai por uma porta, entrando no seu quarto está no seu leito de morte com Virgília (cena do início do filme). O narrador então informa ao espectador que Virgília era a senhora que estava em seus últimos momentos: "Virgília é a senhora que em 1869 iria assistir aos meus últimos momentos; e antes disso, muito antes, teve grande participação nas minhas mais íntimas sensações" (KLOTZEL \& TORERO, 1998, p. 34).

Brás então entra pela porta da sala onde Virgília (ainda jovem) e logo a apresenta para o espectador e avisa que o romance vai começar: "Essa é Virgília jovem. Virgília! Era talvez a mais atrevida criatura de nossa raça humana, e com certeza, a mais voluntariosa. Eu logo iria me encontrar com ela. Logo vai começar o romance" (KLOTZEL \& TORERO, 1998, p. 35).

Já na sequência 44, Brás Cubas retorna para a sala onde estavam Brás Cubas e seu pai, avisando ao espectador que deixará a história sem interrupções: "Mas vamos seguir a história sem interrupções. Por enquanto estamos com meu pai com a xícara de café na boca quando...” (KLOTZEL \& TORERO, 1998, p. 35).

Brasil de Sá (2014) nos traz ao plano de visão que a figura do narrador defunto autor comporta-se como alguém dicotômico/contraditório, expressando em sua atuação uma performance narrativa que se equilibra e retine entre a vida e a morte, o que imprime uma força de estilo inerente à obra machadiana, pois

\footnotetext{
Machado abre o romance fazendo uso de um tom cáustico, sombrio, indício de como será o seu romance e de como vê a humanidade: cada um por si, com sua própria vaidade e mesquinhez, procurando sempre mostrar sua superioridade e buscando a notoriedade na esfera social. (FREITAS, 2007, p. 62)
}

É interessante assinalar que os paratextos "Prólogo da $4^{\circ}$ edição" e "Ao leitor", refletem a dicotomia/dualidade entre o autor e o narrador/autor "Brás Cubas", conduzindo 
o leitor a experimentar uma percepção distinta daquela que experenciada com o que está elaborado no interior da narrativa, um aspecto ressaltado por Pereira, em que

\begin{abstract}
Logo no início do livro, dilui-se a distinção ou dualidade entre autor e narrador - até então claramente definida dentro da narrativa romanesca, para em seguida estabelecer-se a posição ocupada por cada um. Na capa da obra o escritor se apresenta como Machado de Assis, já a dedicatória é feita pelo defunto, autor ficcional das memórias, de forma a construir bases sólidas, reforçadas pela recorrência à metadiscursividade, para que seu discurso seja tomado como verdade e não como simulação desta. (PEREIRA, 2008, p. 44)
\end{abstract}

Por sua vez, o Brás Cubas da percepção de defunto autor da adaptação Klotzel faz uso da simpatia e do (ácido) humor como estratégia para aproximar do leitor, o estabelecendo uma espécie de familiaridade com o espectador para então, com a confiança conquistada, exercer o papel de guia e conduzi-lo pela narrativa. Neste sentido, percebemos que

O cineasta também faz uma atualização do linguajar do narrador e das personagens, trocando termos eruditos e poucos usados, por outros e uso mais corrente ao receptor contemporâneo. Isto garante uma maior aproximação do espectador com o filme. (ALVES, 2013, p. 164)

No limiar da vida, como Soares \& Mello (2017), o fenecimento de Brás Cubas parece lhe conferir plena justificação ao exercício de uma potência com valor simbólico - a qual não lhe fora possível nem oportuno em vida e, ao "autorizar" sua expressão narrativa em primeira pessoa. Compreendemos, portanto, a morte como o não dito na narrativa do defunto-autor, por meio da qual se comunica com a subjetividade do leitor do romance, assim como o faz com o espectador da produção fílmica - ainda que este venha a considerar a morte como uma experiência menor do que aquilo que cogitava ao longo da vida experimentar como seu encerramento da consciência.

\title{
CONSIDERAÇÕES FINAIS
}

É possível considerar, portanto, que o processo de transposição midiática irá desvendar as possibilidades matérias presente em cada mídia para que se obtenha o desenvolvimento satisfatório da Intermidialidade entre o texto de partida (texto literário) 
e o texto de chegada (obra de chegada), ressignificando a narrativa literária a luz da transposição midial e nos mostra como os textos literários têm buscado e alcançado sua autonomia significativa ao ser adaptado para mídia cinematográfica

A construção do defunto autor machadiano através da perspectiva comparada na narrativa literária de Machado de Assis e na narrativa fílmica de André Klotzel. A composição das narrativas nas mídias literária e fílmica, destacamos o que podemos considerar como performance literária de relativa originalidade do romance machadiano, a qual foi captada na produção fílmica de Klotzel, com relação à descrição da gênese de Brás Cubas como defunto autor. Constatamos uma contradição/distinção interior, entre o Brás Cubas defunto autor e o Brás Cubas narrador personagem, a qual elucidamos como a disposição afetiva resultante do paradoxo de dois Brás Cubas distintos, mas complementares para a construção da narrativa.

\section{Referências}

ALVES, B. W. Da Literatura ao Cinema: o narrador Brás Cubas no romance machadiano e na obra fílmica de Klotzel. Dissertação (Mestrado em Estudo de Linguagens) Universidade Federal do Mato Grosso do Sul, Campo Grande, 2013.

ASSIS, M. de. Memória Póstumas de Brás Cubas. In: Todos os romances e contos consagrados: volume 2. 1. ed. - Rio de Janeiro: Nova Fronteira, 2016.

BOSI, A. Brás Cubas em três versões. In: Teresa revista de Literatura Brasileira, vol. 6, n. 7, 2006. p. 279-317.

BRASIL DE SÁ, M. E. A Dramaticidade Tragicômica De Machado De Assis. Revista Entrelaces. Ano IV, nº4 - set., 2014

CLÜVER, C. Intermidialidade. Pós: Belo Horizonte, v.1 n.2, p. 8-23, nov. 2011.

DERRIDA, J. A escritura e a diferença. São Paulo: Perspectiva, 1995.

FREITAS, V. A. de. Memórias póstumas de Brás Cubas: transcodificação da literatura ao cinema. 2007, 138. Dissertação (Mestrado em Comuniação), Universidade de Marília - Marília - São Paulo, 2007.

GUIMARÃES, D. A. D. Perspectiva narrativa e estatuto do personagem Brás Cubas. Letras, Curitiba. p. 139-151 dez. 1975.

HUTCHEON, L. Uma teoria da adaptação. Tradução André Cechinel. 2. ed. Florianópolis: Ed. da UFSC, 2013. 
JONHSON, R. Literatura e cinema. Macunaíma: do modernismo na literatura ao cinema novo. São Paulo: T. A. Queiroz, 1982.

KLOTZEL, A. Memórias Póstumas. Roteiro: André Klotzel. Diálogo: José Torero, 1998. . Uma questão de fidelidade. In: http://memoriaspostumas.com.br/index.htm. Acesso em: 15 nov. 2019.

LOUVEL, L. Nuanças do Pictural. In: DINIZ, Thais Flores N. (org.) Intermidialidades e interartes. Desafios da arte contemporânea. Belo Horizonte, UFMG, p.47- 69, 2012.

MELLO, M. E. C. de. Machado de Assis e as polêmicas a partir de ideias francesas. In:

MENDES, L. P. Memórias póstumas de Brás Cubas no cinema em três versões. 2013. Tese. (Doutorado em Literatura Comparada) - Universidade Federal Fluminense, Niterói, 2013.

MÜLlER, A. Além da literatura, aquém do cinema? Considerações sobre a intermidialidade. Outra travessia. Santa Catarina, nº 7, p. 47-53, 2008.

NUTO, Rosângela Cavalcante. Filmando literatura brasileira: adaptações de Memórias póstumas de Brás Cubas por Julio Bressane e André Klotzel. 2006. 130 f. Dissertação (Mestrado em Comunicação) - Universidade de Brasília, Brasília, 2006.

PEREIRA, G. C. Brás Cubas: Discurso e metadiscurso na construção da personagem no romance e no filme. Dissertação (mestrado) - Universidade Federal de Pernambuco. CAC. Letras, 2008, $114 \mathrm{f}$.

PESSOA, P. A segunda vida de Brás Cubas: a filosofia da arte de Machado de Assis. Rio de Janeiro: Rocco, 2008.

RIBAS, M. C. C.; NUNEZ, C.P.F. Diálogos contemporâneos: da palavra ao écran. In: Passages de Paris (APEB-Fr), v. 13, p. 493-511, 2016.

Modos de ver, modos de ler, modos de ser: tópicos de transposição midial. In: Anais do XV Congresso Internacional da Associação Brasileira de Literatura Comparada, v.02, p. 2878- 2885, Rio de Janeiro, 2017.

RAJEWSKY, I. Intermidialidade, intertextualidade e "Remediação" - Uma perspectiva literária sobre a Intermidialidade. In: DINIZ, Thais Flores N. (org.) Intermidialidades e interartes. Desafios da arte contemporânea. Belo Horizonte, UFMG, 2012a. p. 15-46.

A fronteira em discussão: o status problemático das fronteiras midiáticas no debate contemporâneo sobre intermidialidade. In: DINIZ, Thais Flores Nogueira; Vieira, André Soares (org). Intermidialidade e estudo interartes: Desafios da arte contemporânea. vol. 2. Belo Horizonte, Rona Editora: Fale/UFMG, 2012 b. 
ROCHA, E. V. P. da. Uma análise da volubilidade do narrador machadiano no romance Memórias Póstumas de Brás Cubas. Monografia (Especialização em Literatura Brasileira) - Universidade Católica de Brasília, 2016.

SABADIN, Celso. Memórias póstumas. 15 de agosto de 2001. http://br.cinema. yahoo.com/dvd/filme.

SILVA JUNIOR, A. R. da; NETO, M. E. de P. Brás cubas e memórias póstumas: cinema de poesia, tradução coletiva e tanatografia. In: Anais do Colóquio Internacional Vicente e Dora Ferreira da Silva e do Seminário de Poesia - Poesia, Filosofia e Imaginário. Volume 1, Número 1. Uberlândia: ILEEL, 2015.

SOARES, J. B.; MELLO, M. M. de. A morte como recurso para o não dito em Memórias Póstumas de Brás Cubas. In: Olho d'água, São José do Rio Preto, v. 9, n. 1, jan. jun./2017. p. 1-23.

STAM, R. Teoria e Pratica da Adaptação: Da Fidelidade à Intertextualidade. Revista Ilha do Desterro. Florianópolis, 2006.

VILLAÇA, P. Memórias Póstumas, 2001.

https://cinemaemcena.com.br/critica/filme/6846/memorias-postumas.

Acesso em: 20 dez. 2020.

Recebido em: 31/05/2021

Aceito em: 31/07/2021 